
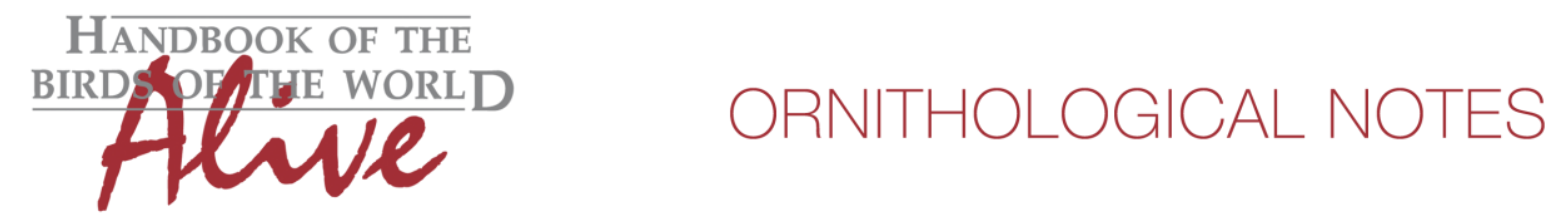

\title{
Notes on the vocalizations of Sulphur-rumped Flycatcher (Myiobius sulphureipygius), Whiskered Flycatcher (Myiobius barbatus) and Black-tailed Flycatcher (Myiobius atricaudus)
}

Peter Boesman

In the following we briefly analyze and compare voice of the different races of Sulphurrumped Flycatcher (Myiobius sulphureipygius), Whiskered Flycatcher (Myiobius barbatus) and Black-tailed Flycatcher (Myiobius atricaudus). We also try to quantify the extent of any vocal differences using the criteria proposed by Tobias et al. (2010), as a support for taxonomic review. We have made use of sound recordings available on-line from Xeno Canto (XC) and Macaulay Library (ML).

Myiobius flycatchers are particularly unvocal, and when vocalizing, most often this is limited to a single very short note. We have examined all available recordings on-line of the lowland Myiobius flycatchers. Given that over most of the geographical range of these similar-looking flycatchers two taxa can be observed, there is also a potential identification pitfall.

\section{Myiobius sulphureipygius}

Several sources describe a song, but indicate that the species does not sing often. The song is a rising and falling series of 4-6 lilting, clear notes, tseuu tseuu tseuu tseer tseer or tchew tchew tchew tchew tchew with variants (Stiles and Skutch 1989, Howell and Webb 1995). The dawn song is a rapidly repeated chu wee-da-wiit' or chu wee-da-ti-wit (Howell and Webb 1995). Its call is described as a low, sharp, dry psit or spik or fit or pit or a wet, fairly sharp plik or pic (Skutch 1960, Stiles and Skutch 1989, Howell and Webb 1995). This call frequently is used while foraging and during other daily activities.

We located 13 recordings. 11 recordings are of a very short note "spik!" which shows as a vertical line on a sonogram with very large frequency range. 1 recording had similar but doubled notes, 1 recording was different and may actually be atricaudatus. We did not find any recording which resembles the descriptions of 'song'.

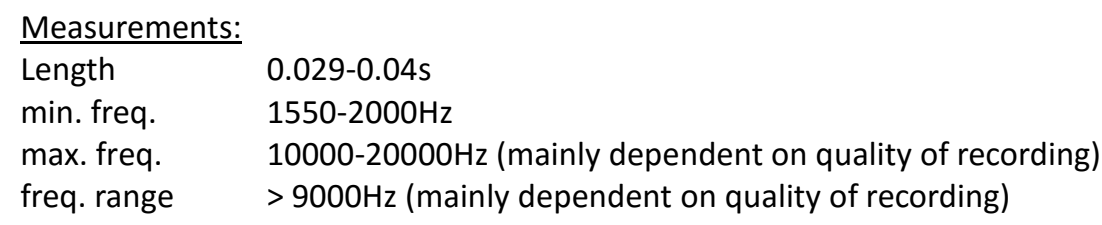

M. s. sulphureipygius and M. s. aureatus have an identical call. 

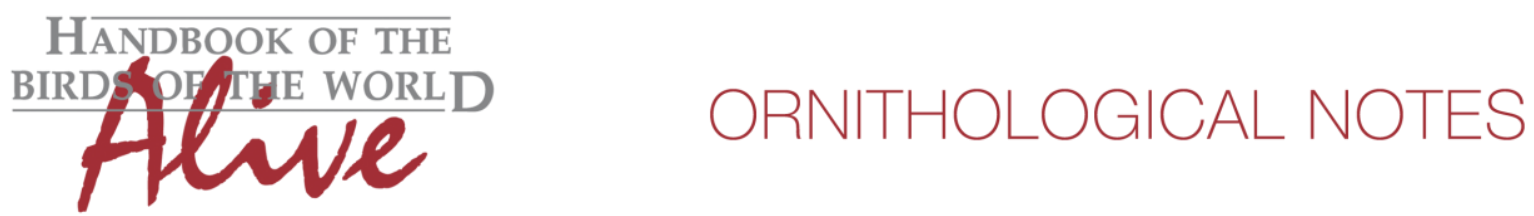

\section{Myiobius barbatus}

HBW (Farnsworth et al. 2015) mentions for voice: Generally silent; sometimes a high sharp "tsip" or "psik" call note. We located 21 recordings.

Amazonian birds: M. b. semiflavus, M. b. barbatus, M. b. amazonicus

Vocabulary seems to be more varied than sulphureipygius:

a. a short rising note "wit!" (6 recordings)

Length $\quad 0.044-0.09 \mathrm{~s}$

min. freq. $\quad 3000-4350 \mathrm{~Hz}$

max. freq. $\quad 6500-7400 \mathrm{~Hz}$

freq. range $\quad 2200-3800 \mathrm{~Hz}$

b. an overslurred "psiw" (4 recordings) (asymmetric with 'second leg' longest and lowest in freq.)

Length $\quad 0.10-0.19 \mathrm{~s}$

min. freq. $\quad 2600-4250 \mathrm{~Hz}$

max. freq. $\quad 5100-6300 \mathrm{~Hz}$

freq. range $\quad 2000-2800 \mathrm{~Hz}$

c. a longer phrase starting with the "psiw note" (2 recordings): "psiw..tsew" and "psiw..wit..wit..wit..wit".

d. an overslurred note "wheet" (2 recordings) (symmetric on sonogram)

Length $\quad 0.12-0.16 \mathrm{~s}$

e. a short "spik" (1 recording) similar to sulphureipygius

Atlantic birds: M. b. insignis M. b. mastacalis

a. a short rising note "wit!" (4 recordings)

$\begin{array}{ll}\text { Length } & 0.050-0.070 \mathrm{~s} \\ \text { min. freq. } & 3400-4800 \mathrm{~Hz} \\ \text { max. freq. } & 6500-7400 \mathrm{~Hz} \\ \text { freq. range } & 2200-3500 \mathrm{~Hz}\end{array}$

b. a short liquid "psit" (4 recordings)

Length $\quad 0.035-0.045 \mathrm{~s}$

min. freq. $\quad 2800-3600 \mathrm{~Hz}$

max. freq. $\quad 6500-7050 \mathrm{~Hz}$

freq. range $\quad 2900-4100 \mathrm{~Hz}$

c. an overslurred "psiw" (1 recordings) (asymmetric with 'second leg' longest and lowest in freq.)

Length $\quad 0.12 \mathrm{~s}$

min. freq. $\quad 3600 \mathrm{~Hz}$

max. freq. $\quad 6700 \mathrm{~Hz}$

freq. range $3100 \mathrm{~Hz}$

d. a longer phrase (2 recordings): "psiw..tsew" and "wit..tsew". 

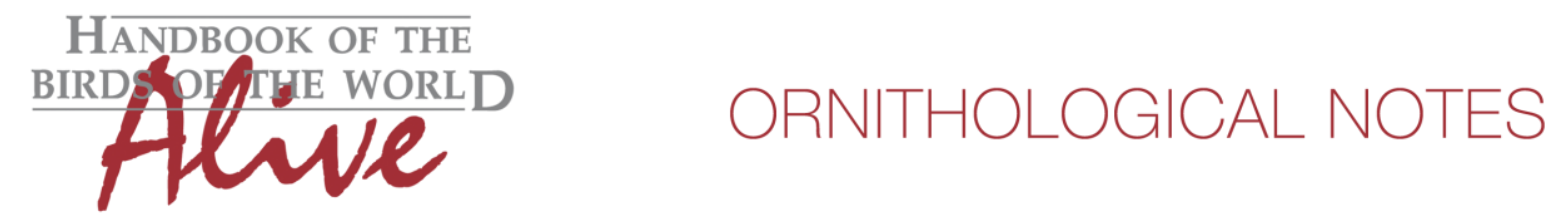

\section{Myiobius atricaudus}

HBW mentions: Generally quiet; call a soft wiry "tsit" or "wit", weaker than that of $M$. sulphureipygius; song a sweet "cheer-cheer-cheer".

We located 11 recordings.

Vocabulary seems to be quite varied, and the few recordings don't allow to evaluate any possible differences between birds from Atlantic Brazil and other races.

As a matter of fact, the identification pitfall barbatus/atricaudatus in the field also puts some uncertainty on the recordings of both species (where they occur together). Furthermore, 3 recordings seem to be outside the known range, they are either range extensions or wrong identifications...

We found vocalizations similar to the previous species:

* an overslurred symmetrical note (4 recordings)

$*$ a rising note (2 recordings)

* descending notes (1 recording)

* a chatter of $>10$ notes ( 3 recordings)

\section{Conclusion}

The vocabulary of Whiskered Flycatcher M. barbatus is quite varied, Amazonian birds and Atlantic birds have quite a similar range of vocalizations, although there may be some differences which will only be possible to uncover when more recordings become available. Black-tailed Flycatcher $M$. atricaudatus seems to have some unique vocalizations such as a rapid sequence of notes, but the few recordings don't allow to define main vocalizations. No differences between Atlantic birds and others can be substantiated.

The only taxa which clearly stand apart are M. s. sulphureipygius/aureatus, which seem to utter only one type of single note, quite different from all other lowland Myiobius taxa. This call note has by far the highest frequency range (score 3 ) and is extremely short (score 1-2). Although this call note has presumably also been recorded for Amazonian M. barbatus, it is definitely not a main vocalization.

Based on this analysis and if we apply Tobias criteria on call notes, quantification of vocal difference of M. s. sulphureipygius/aureatus versus all taxa in M. barbatus leads to a score of about 4.

This note was finalized on 3rd July 2015, using sound recordings available on-line at that moment. We would like to thank in particular the many sound recordists who placed their recordings for this species on $\mathrm{XC}$ and $\mathrm{ML}$.

\section{References}

Farnsworth, A. \& Lebbin, D. (2015). Whiskered Flycatcher (Myiobius barbatus). In: del Hoyo, J., Elliott, A., Sargatal, J., Christie, D.A. \& de Juana, E. (eds.). Handbook of the Birds of the World Alive. Lynx Edicions, Barcelona. (retrieved from http://www.hbw.com/node/57336 on 2 July 2015).

Howell, S.N.G, Webb, S. (1995). A guide to the birds of Mexico and Northern Central America. Oxford University Press, New York. 
Stiles, F.G. \& Skutch, A.F. (1989). A Guide to the Birds of Costa Rica. Christopher Helm, London.

Tobias, J.A., Seddon, N., Spottiswoode, C.N., Pilgrim, J.D., Fishpool, L.D.C. \& Collar, N.J. (2010). Quantitative criteria for species delimitation. Ibis 152(4): 724-746.

\section{Recommended citation}

Boesman, P. (2016). Notes on the vocalizations of Sulphur-rumped Flycatcher (Myiobius sulphureipygius), Whiskered Flycatcher (Myiobius barbatus) and Black-tailed Flycatcher (Myiobius atricaudus). HBW Alive Ornithological Note 112. In: Handbook of the Birds of the World Alive. Lynx Edicions, Barcelona. (retrieved from http://www.hbw.com/node/932017 on 2 August 2016). 